\title{
Seasonal variability in microplanktonic biomasses in the Gironde dilution plume (Bay of Biscay): relative importance of bacteria
}

\author{
Luis Felipe ARTIGAS
}

Laboratoire d'océanographie biologique (UMR 5805), Université Bordeaux-I, avenue des Facultés, 33405 Talence cedex, France

(Received 19/02/97, revised 05/05/98, accepted 11/05/98)

\begin{abstract}
Bacterial and phytoplankton biomasses were estimated in a four-year study along a saline gradient (the dilution plume of the Gironde estuary on the Aquitanian continental shelf), by measuring bacterial abundance and mean cell volumes (epifluorescence counts) and chlorophyll- $a$ concentrations (in vitro fluorescence). The spatial and temporal distribution of phytoplankton enabled us to determine the seasonal succession of algal blooms, sprouting in the marine waters of the inner shelf in early spring (picoplanktonic forms), reaching their annual maximum $\left(10 \mu \mathrm{g} \mathrm{L}{ }^{-1}\right)$ in plume waters in advanced spring, and moving to estuarine waters in the summer ( $>20 \mu \mathrm{m}$ forms). Bacterial biomasses followed mainly a decreasing dilution gradient, especially in winter and early spring, with maximum estuarine values reaching $10^{7}$ cell $\mathrm{mL}^{-1}$ (more than $30 \%$ of small attached cells and more than $60 \%$ of free small cocci), in accordance with estuarine discharges into the inner shelf zone. Moreover, plume waters showed an additionnal peak of bacterial numbers and mean cell volumes in early summer, with increasing proportions of larger rod- and vibrio-shaped bacteria. A clear morphometrical succession was followed in marine waters, from a majority of attached and coccal cells in winter, to maximal proportions of larger vibrio-shaped bacteria, inducing a maximal spring level of total abundance $\left(2 \times 10^{6} \mathrm{cell} \mathrm{mL}^{-1}\right)$ and high mean cell volumes $\left(0.044 \mu \mathrm{m}^{3}\right)$, coinciding with the marine vernal bloom. Bacterial estimated biomass represented, consequently, a wide range of proportions compared to phytoplankton: only when a good correlation was found between them, bacterial-C/phytoplankton-C ratio was close to $1 / 4$, a correlation that improved in warmer periods, throughout different water types. Due to the relavitely narrow range of chlorophyll- $a$ values, we could not find a high predictive correlation when pooling all the 4-year data, a relationship that has been outlined in important reviews by pooling together different aquatic systems. We noticed, however, that in the particular environment of our study (high inputs of particulate detritic matter) bacterial-C usually dominated the microbial pool (specially in estuarine and plume waters and in light-limited conditions). This dominance, added to the frequent dominance of small-sized phytoplankton, leads to an enhanced "microbial loop" activity, defining a "maintenance system" (oligotrophic conditions), which alternates with some eutrophic periods. (C) Elsevier, Paris
\end{abstract}

bacterioplankton / phytoplankton / microbial biomass ratio / seasonal variability / Gironde dilution plume

Résumé - Variabilité saisonnière des biomasses microplanctoniques dans le panache girondin (golfe de Gascogne) : importance des bactéries. Les biomasses bactériennes et phytoplanctoniques ont été estimées au cours d'une étude menée sur quatre ans, le long d'un gradient halin (panache de dilution girondin, sur le plateau continental Aquitain), par des mesures globales d'abondances et biovolumes bactériens (comptages en épifluorescence) et par des mesures de chlorophylle- $a$ (fluorimétrie extractive). La répartition spatio-temporelle des micro-algues nous a permis de préciser la succession spatiotemporelle de leurs poussées, depuis le début du printemps (formes picoplanctoniques) en eaux marines, vers une situation de poussée de panache (maximum annuel de $10 \mu \mathrm{g} \mathrm{chl}-a \cdot \mathrm{L}^{-1}$ ), puis vers la situation de poussée phytoplanctonique estivale (formes $>20 \mu \mathrm{m}$ ). Un gradient de dilution décroissant caractérise les biomasses bactériennes, spécialement en hiver et au début du printemps, les maxima estuariens atteignant les $10^{7}$ cell. $\mathrm{mL}^{-1}, 30 \%$ de petites bactéries attachées, et plus de $60 \%$ 
de formes coccoïdes libres. Les eaux de panache ont présenté un pic de biomasses à la transition printemps-été, avec encore $15 \%$ de bactéries attachées, mais de fortes proportions en grandes formes libres (vibrioïdes et bâtonnets). En eaux marines, on décèle une succession morphométrique, avec une majorité de bactéries attachées et coccoïdes en hiver, alors que les formes libres vibriödes sont fortement représentées au printemps, provoquant, au moment du bloom algal, un niveau maximal d'abondances $\left(2 \times 10^{6}\right.$ cell. $\left.\mathrm{mL}^{-1}\right)$ et de volumes moyens cellulaires bactériens $\left(0,044 \mathrm{um}^{3}\right)$. L'importance relative des biomasses bactériennes par rapport au phytoplancton est par conséquent extrêmement variable, et la relation établie entre les deux stocks, lorsqu'elle existe, est d'autant plus significative que l'on avance dans la saison, le rapport moyen C-bact/C-phyto étant de 1/4. En raison du manque de représentativité des fortes concentrations chlorophylliennes dans cette étude, nous n'avons pas retrouvé la corrélation hautement significative décrite dans les synthèses bibliographiques, englobant un bon nombre de systèmes aquatiques. Nous avons toutefois remarqué que, dans cet environnement particulier (importants apports particulaires détritiques), le C-bactérien domine le plus souvent au sein du pool de biomasse microbienne (surtout en eaux dessalées, et lors des périodes de limitation par la lumière). Cette dominance bactérienne, ajoutée à la présence d'un phytoplancton de petites dimensions, dénote d'une activité accrue de la «boucle microbienne », et permet de caractériser un système de «maintenance » (conditions oligotrophes), alternant au cours des saisons avec quelques périodes eutrophes. () Elsevier, Paris

\section{bactéries / phytoplancton / rapport des biomasses microbiennes / variabilité saisonnière / panache de dilution girondin}

\section{INTRODUCTION}

In the last thirty years, new direct methods have been developed in microbial ecology which allow the increasing importance of bacterial biomass and production in aquatic ecosystems to be shown. Playing a key role in the remineralization of organic matter, bacteria also represents quite an important microplanktonic organic matter pool, that fluctuates all over the seasons, more or less available to predators, in what Azam et al. [6] called the 'microbial loop'.

Even though the relationship between phytoplankton and bacteria has been pointed out in several studies and reviews concerning fresh, brackish and marine ecosystems $[11,13,16,27,61]$, recent studies over a monthly, seasonal or inter-annual scale have shown a lack of covariation of those components of microbial biomass [14,24, $34,46]$. In fact, a time gap found between algae and bacterial seasonal development was supposed to convey a bacterial 'response' to phytoplankton dynamics, occuring days/weeks later than the algal bloom [15, 28, 47, 68].

In coastal zones, allochthonous inputs of organic matter and associated-microplankton from rivers and estuaries may be important and may alter or determine rhythms of microplanktonic seasonal and inter-annual dynamics. In fact, bacterial growth can be highly influenced by allochtonous inputs of organic matter and by mixing processes, which can interfere in the photosynthetic-derived- $\mathrm{C}$ control of bacterial growth (extracellular phytoplankton release, [7]). 'Normal' relationships between bacteria and phytoplankton, as they have been defined in the crosssystem reviews cited above, may be disrupted in river plumes $[23,40]$.

By studying the Aquitanian shelf under direct influence of the macrotidal and highly turbid Gironde estuary over four years (1992-1995), the author wanted to determine whether or not bacteria represented an important part of microplankton stocks throughout the year in this coastal and shelf area, which had never been sampled in a coupled bacteria-phytoplankton study.

To begin with, the principal patterns of variability of both stocks have heen defined over all the seasons, across different years, by completing the delimitation of different seasonal situations, pre-defined in a previous study on temperature and chlorophyll- $a$ distribution in surface waters [4]. For this purpose, the salinity parameter appeared to be the most discriminant one.

In order to separate seasonal patterns of variation of both microbial parameters in the different types of water masses meeting at the Aquitanian inner shelf, the isohaline of 30 was taken as the upper boundary of estuarine discharge in coastal waters and the lower limit of dilution plume shelf waters, and the isohaline of 34 , as the upper limit of dilution plume and the lower limit of marine shelf waters [9]. Afterwards, both microplanktonic biomasses variability was summarised by comparing the bacteria/ phytoplankton carbon-ratio along the year, and by testing the eventual correlations between both microbial stocks. 
The relative importance of bacterial carbon (bact-C) was also approached by a comparison with the particulate organic carbon (POC), at three different spring situations, in order to complete our understanding of the two major components of microplanktonic-C.

\section{MATERIALS AND METHODS}

\subsection{Sampling}

This study concerned the immediate zone off the mouth of the Gironde estuary, from where transects East-West, East-SW and East-NW were done. The sampling network was essentially determined by weather conditions, and was mainly conducted on a 20 m-long coastal ship, the 'Côte d'Aquitaine' (CNRS-INSU). In 16 surveys from three days to three weeks (1992-1995), most of the extent of what is called the 'dilution plume of the Gironde estuary' and part of the inner Aquitanian shelf directly influenced by this coastal plume were sampled (figure I). The missions were part of the 'Programme National d'Océanographie Côtière' (PNOC), the 'ECOMARGE' programme and the Programme National de Télédetection Satellitale' (PNTS, 'CALIBSAT' cruises), and werc carried out on different dates (table I).

\subsection{Hydrography and particulate matter analysis}

Temperature, conductivity (and derived salinity) and depth were recorded mainly by a SBE 25-03 sea logger CTD, except on the 1992 cruises, when a Zullig and a M.E.-GMBA CTD were employed.

Suspended Particulate Matter (SPM) concentration was determined by filtering surface waters collected in Niskin bottles or in distillate-water-rinsed buckets, into previously weighed GF/C (Whatman) filters, which were afterwards dried at $60^{\circ} \mathrm{C}$ overnight, and weighed again. The organic part of suspended matter was determined only in spring using a CHN autoanalyser (Carlo-Erba), after filtration onto pre-calcinated GF/F (Whatman) filters and after an overnight decarbonatation period with $\mathrm{HCl}$ fumes [41].

\subsection{Phytoplankton and bacterioplankton}

Water samples were taken using $5 \mathrm{I}$, or $8 \mathrm{I}$, acid-washed and water-rinsed Niskin bottles, at different depths (essentially in surface and euphotic zone waters).

Subsamples for pigment analysis were pre-filtered through nylon meshes of 300 or $200 \mu \mathrm{m}$, in order to eliminate as much zooplankton as possible. Then, 0.25 to $1.5 \mathrm{~L}$ of them were filtered into $\mathrm{GF} / \mathrm{F}$ Whatman glassfibre filters. Filters were stored frozen at $-20^{\circ} \mathrm{C}$ in the dark until analysis. In the lahoratory, they were ground and then extracted overnight at $4{ }^{\circ} \mathrm{C}$ with $90 \%$ acetone [62].

Chlorophyll- $a$ (chl- $a$ ) and degraded pigments (phaeopigments) were determined by the fluorescence method [70], before and after adding $\mathrm{HCl}$ at $0.03 \mathrm{M}$, on a Turner Designs (model 10-005) fluorometer. Pigments were expressed directly in $\mu$ g of chlorophyll- $a$ equivalents per L [17]. Microphytoplankton (20-200 $\mu \mathrm{m})$, nanophytoplankton $(3-20 \mu \mathrm{m})$ and picophytoplankton $(0.4-3 \mu \mathrm{m})$ proportions were determined only on some spring cruises, using different successive filtrations: pre-filtration through nylon meshes of 200 and $20 \mu \mathrm{m}$, and filtration through 3 and $0.4 \mu \mathrm{m}$ Nuclepore filters.

Subsamples for bacterial measures were collected on pressure-sealed sterilized $60 \mathrm{~mL}$ glass flasks. They were immediately preserved in borate-buffered filtered formalin (final concentration $5 \%$ ), and stored at $4{ }^{\circ} \mathrm{C}$ until being filtered, less than two months later, in order to min-

Table I. Dates of the cruises on the Aquitanian Shelf, corresponding to the 8 different seasonal situations (capital letters) defined in the text (see also figure 3).

\begin{tabular}{|c|c|c|c|c|c|c|c|c|}
\hline & $\mathbf{A}$ & B & $\mathbf{C}$ & D & $\mathbf{E}$ & $\mathbf{F}$ & G & $\mathbf{H}$ \\
\hline $\begin{array}{l}\text { Seasonal } \\
\text { Situation }\end{array}$ & Winter & $\begin{array}{c}\text { Winter-Spring } \\
\text { Transition }\end{array}$ & Early Spring & $\begin{array}{l}\text { Inner-Shelf } \\
\text { Spring Bloom }\end{array}$ & $\begin{array}{c}\text { Plume } \\
\text { Advanced- } \\
\text { Spring Bloom }\end{array}$ & $\begin{array}{c}\text { Spring- } \\
\text { Summer } \\
\text { Transition }\end{array}$ & $\begin{array}{c}\text { Estuarine } \\
\text { Summer } \\
\text { Bloom }\end{array}$ & Autumn \\
\hline 1992 & - & $03 / 01$ & $03 / 26-30$ & - & $05 / 06-08$ & 07/02-04 & - & $09 / 26-10 / 01$ \\
\hline 1993 & $02 / 10-13$ & $03 / 23-24$ & $04 / 04-18$ & - & $05 / 25-30$ & 06/14-18 & $07 / 28-29$ & $10 / 13-14$ \\
\hline 1994 & $01 / 31-02 / 02$ & - & - & $\stackrel{-}{-}$ & $05 / 03-17$ & $07 / 08-13$ & - & - \\
\hline 1995 & - & - & - & $05 / 18-26$ & - & - & - & - \\
\hline
\end{tabular}


$W 2^{\circ} 30 \quad 2^{\circ} 110^{\prime}$

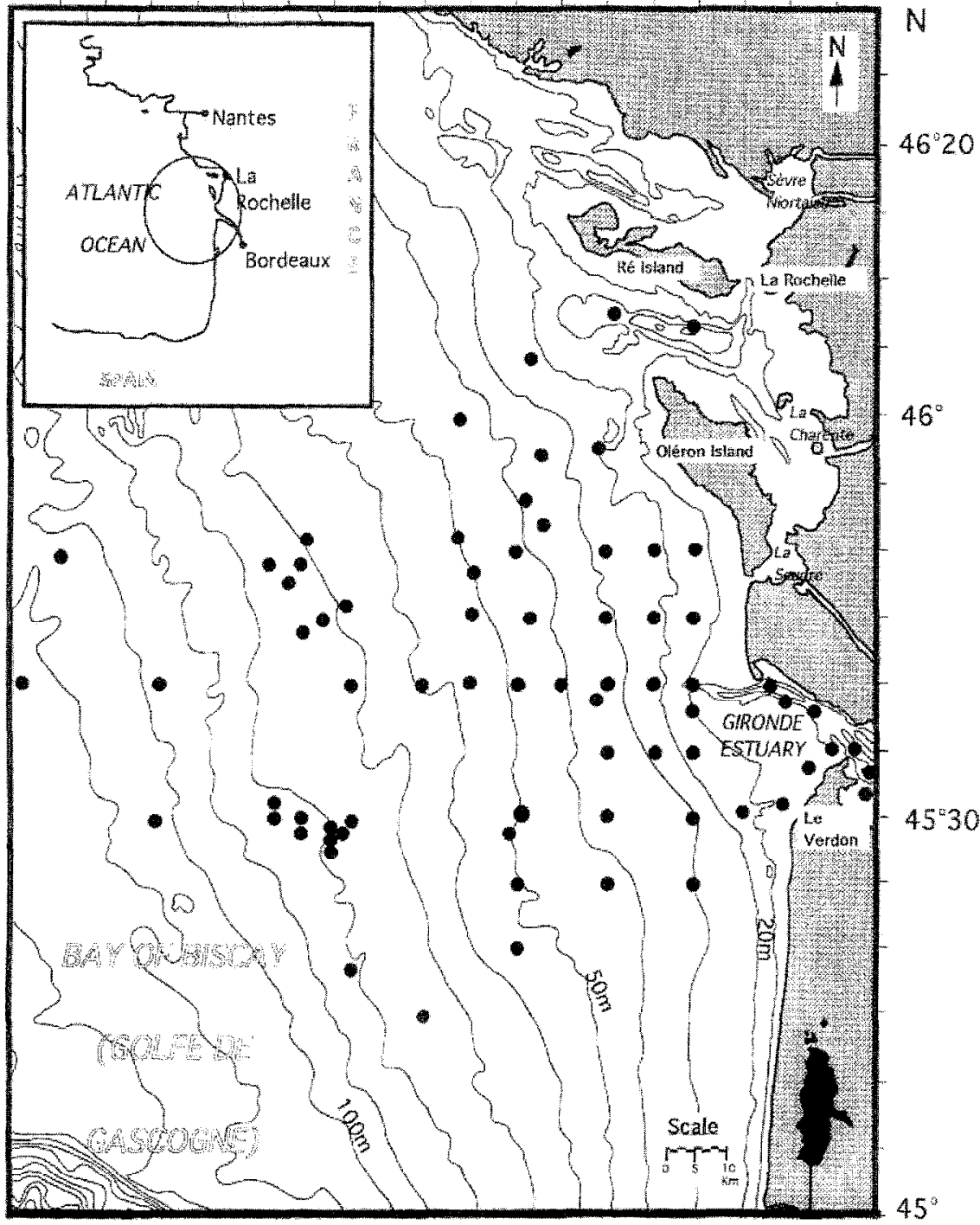

Figure 1. Sampling Area for 1992, 1993, 1994 and 1995 cruises on the dilution plume of the Gironde estuary and the Aquitanian shelf: "ECOMARGE 92-93", "PNOCAT93-94", "CALIBSAT93-94", "BIOMET95".

imize the decrease in bacterial cell numbers due to storage [67]. Subsamples were mixed before being stained.

Bacterial numbers were determined by the epifluorescence direct counting method, using the 4,6-diamidino-2phenyl-indole (DAPI) employed at a $1 \mu \mathrm{g} \mathrm{mL} \mathrm{m}^{-1}$ final concentration, during $15 \mathrm{~min}$ of staining [53]. The Acridine Orange (A.O.) method was employed only in 1992 according to the protocol of Daley and Hobbie [18], modified by Torréton [64], at a final concentration of $0.01 \%$, during a $5 \mathrm{~min}$ incubation. DAPI staining was preferred afterwards because of the lower interference of staining particulate organic matter, particularly abundant in estuarine and turbid plume waters [5]. In both cases, $0.2 \mu \mathrm{m}$ filtered solutions of nucleic acid dye were used.

Subsamples of $5 \mathrm{~mL}, 1 \mathrm{~mL}$ or less, were filtered immediately after staining with a vacuum pump (less than $10 \mathrm{~mm}$ $\mathrm{Hg}$ ), onto $25 \mathrm{~mm}$-diameter and $0.2 \mu \mathrm{m}$ pore-size Isopore black-coloured filters (GTBP, Millipore), which had been mounted onto $\mathrm{GF} / \mathrm{C}$ (Whatman) filters, in order to have a better distribution of filtered cells. The sub-sample was completed with $0.2 \mu \mathrm{m}$ filtered artificial sea water, in order to have a minimal volume (a blank was conducted 
regularly in order to verify that there were no bacteria in the dilution water). Dilutions of $10^{-1}$ or $10^{-2}$ were carried out in high turbid waters.

The filters were placed on a glass slide between two drops of non fluorescent Olympus immersion oil and analyzed at a wavelength of $365 \mathrm{~nm}$ using Nachet NS 200 (A.O.) and Olympus BH2 RFCA (DAPI) microscopes (magnification $\times 1,250$ ). Free-living and attached bacteria were counted simultaneously and cells observed within, on, or immediately adjacent to a particle were assumed to be attached to the particle [26]. Each filter was examined to ensure an equal distribution of cells on it. Ten fields of no less than 30 bacteria per field were counted, e.g. a minimum of 300 bacteria per filter.

Bacterial cell volume was estimated from microphotographs (Kodak Ektachrome ASA 100). Pholographs were taken of three or four randomly selected fields from each microscope slide, in order to have a minimum of $60 \mathrm{bac}-$ terial cells. Photographic images were measured with a micrometric grid as reference, according to the criteria of Lee and Fuhrman [43], and Torréton [64], categorizing cells as rods, cocci, vibrio and ' $S$ ' forms, and cutting off the dim fluorescent 'halo' around the cell image. Mean cell volume was then calculated treating rods, vibrio and 'S' forms as cylinders plus hemispheres at each end, and cocci as spheres, respectively.

\subsection{Biomass Calculation}

Phytoplankton biomass was calculated directly from chlorophyll- $a$ concentration by a mean conversion factor currently used in coastal active waters: $50 \mu \mathrm{g} \mathrm{C}(\mu \mathrm{g} \mathrm{chl}-a)^{-1}$ $[25,54]$. In fact, this factor represents the regression factor (regression line slope) of the regression model applied to chl- $a$ and POC co-variation in batch cultures and/or in natural waters [8]. Nevertheless, this conversion factor remains controversial as it can be temperature-, light-, nutrient- and/or phytoplankton specific compositiondependent [21]. In spite of having obtained some partial correlations in spring time, thanks to punctual POC measures (factor varying between 58 and 222), the fact that no systematic POC data was associated to chl- $a$ measures throughout the year made the use of a common conversion factor [13] more suitable, instead of applying these scarce empirical coefficients.

Bacterial biomass was estimated by multiplying bacterial abundance by the mean cell volume of each subsample, and then, using a conversion factor to transform biovol- ume into biomass. An allometric model was employed, assuming that the dry weight-to-volume ratio was linearly dependent on volume, so that smaller organisms tend to have a higher dry weight-to-volume ratio than larger ones $[48,60]$. Bacterial volumes in this study $(0.01$ to $0.15 \mu \mathrm{m}^{3}$ cell $^{-1}$ ) were completely integrated in Simon and Azam's volume range. Their final carbon estimations per size-class were chosen to determine a carbon-to-volume ratio for each mean cell volume using the following relationship:

Biomass $(\mathrm{fgC})=92 \times$ Biovolume $^{0.6}\left(\mathrm{\mu m}^{3}\right)$

The final carbon content value varied between a mean of $10.0 \mathrm{fg} \mathrm{C} \mathrm{cell}^{-1}(\mathrm{n}=16$; S.D $=0.7)$ in February 1993 and $14.5 \mathrm{fg} \mathrm{C}$ cell $^{-1}(\mathrm{n}=36$; S.D = 2.3) in June 1993. A.O. counts provided a higher carbon content (average of $18.3 \mathrm{fg} \mathrm{C}$ cell $^{-1} ; n=169$; S.D. $=4.0$ ), due to bigger mean cell volumes also found in a comparison of both dyes by Suzuki et al. [63]. Thus, 1992 cell volumes were not included in our estimations of per-season mean cell volumes or per-season mean bacterial biomasses. Nevertheless, A.O. numbers were not significantly different from DAPI ones in the same area [5], in 1993, 1994 and 1995, except in high-turbidity waters, where interference with humic particles made them rise exponentially with dilution and so, only these latter samples were not included in calculations of mean seasonal abundance.

\section{RESULTS}

The hydrological system of the Gironde dilution plume, in spite of an important daily tidal influence, showed a permanent gradient of turbidity and salinity, more accentuated in winter and in spring (when important estuarine discharges occur). In a general way, temperature values followed seasonal dynamics well determined by Barthe [9] and Hermida [33]: in winter, temperature increased with shore distance and with increasing salinity (figure 2). With the spring atmosphere warming, this situation was progressively reversed, the estuarine waters becoming warmer than the shelf ones (figure 2) and, on the inner shelf, the winter thermocline disappeared and was progressively replaced by the summer thermocline, signifying the strongest vertical stratification of the year.

Turbidity, expressed as a suspended particulate matter charge (mg SPM L ${ }^{-1}$ ), was almost always inversely related to salinity (figure 2; [33]), although showing an important decrease on estuarine values in summer. 


\section{SEASONAL EVOLUTION OF TEMPERATURE (1993)}

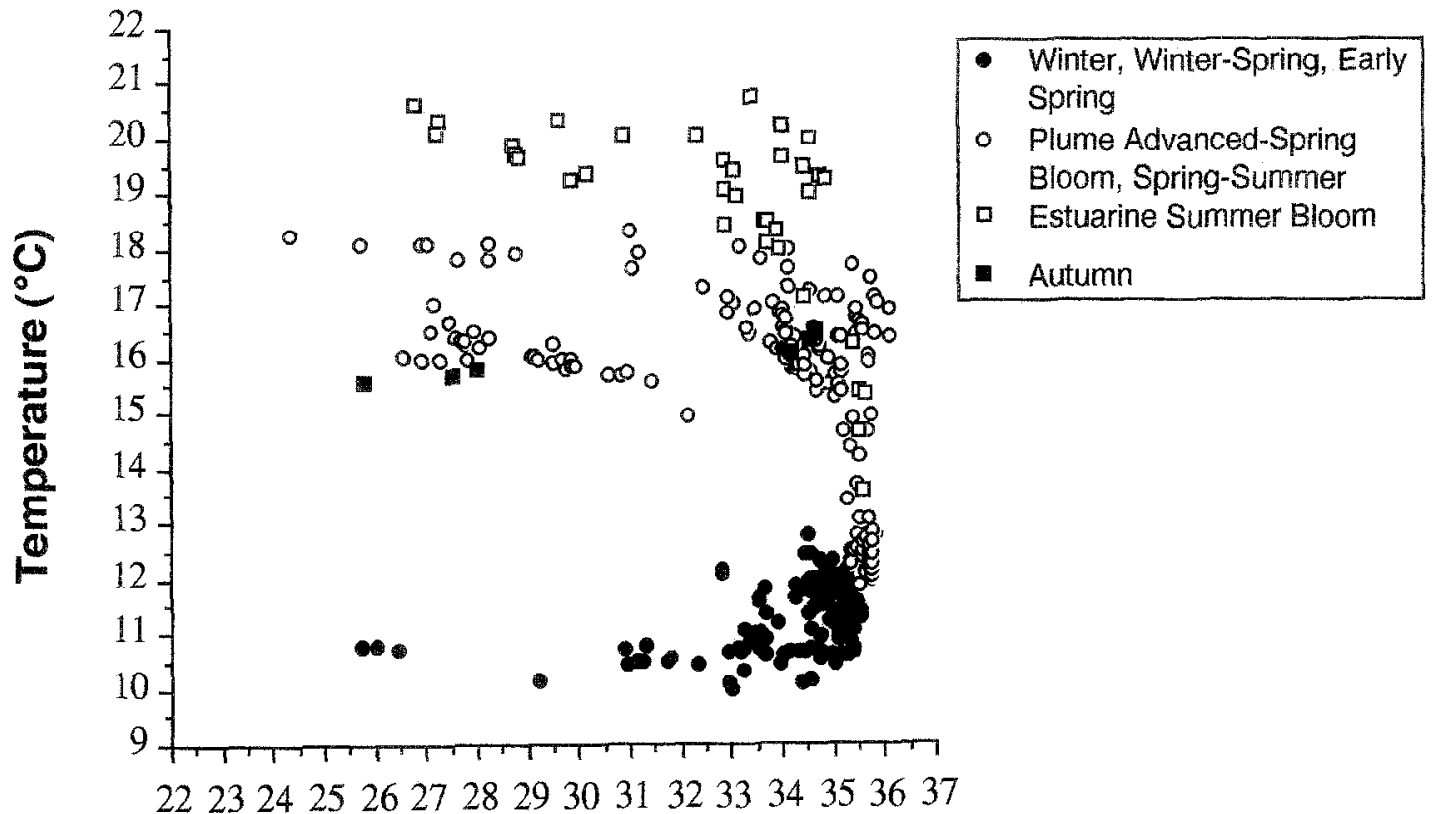

Salinity

\section{SEASONAL EVOLUTION OF TURBIDITY (1993)}

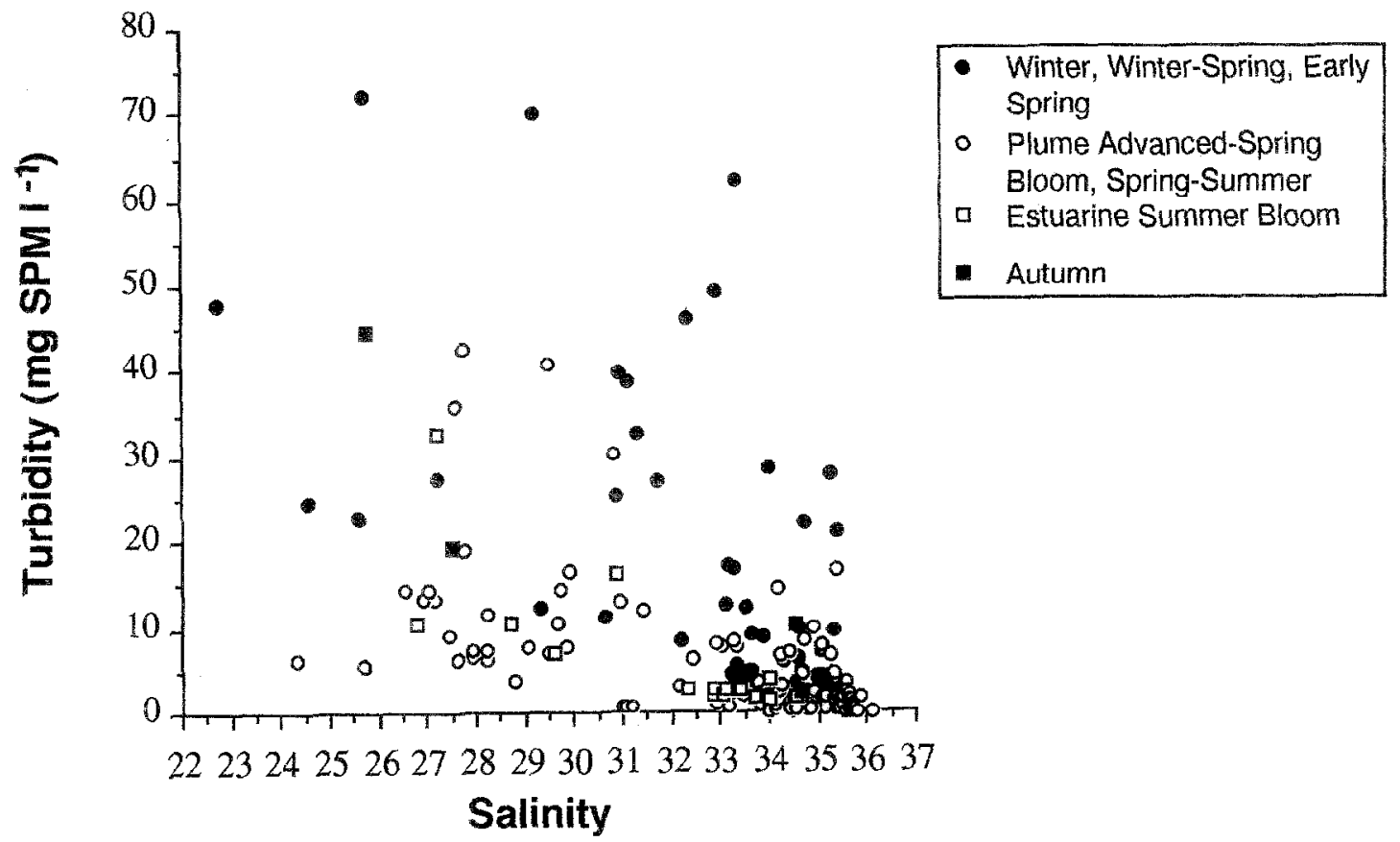

Figure 2. Seasonal distribution (1993) of the temperature (top) and turbidity expressed as suspended particulate matter concentration (bottom) along the saline gradient of the Gironde dilution plume, on the Aquitanian shelf. Flood periods (dark plots) are compared to mid-flow and lowflow periods (open plots). 


\subsection{Seasonal distribution of phytoplankton and bacte- ria along the salinity gradient}

\subsubsection{Chlorophyll-a distribution}

The distribution of chlorophyll- $a$ concentrations in winter and at the beginning of estuarine water warming was marked by the dilution of estuarine pigments on the shelf (figures $3 a, b$ ). Except for a winter chlorophyll peak measured in inner shelf waters in late January 1994 (figure $3 a$ ), the phytoplankton bloom began weakly in early spring (figure $3 c$ ), with an increase of chl-a concentrations $\left(\geq 1.5 \mu \mathrm{g} \mathrm{L}^{-1}\right)$ in waters of salinity 34.5 . In early May 1995 (figure $3 d$ ), the spring bloom was well established in waters of salinity ranging from 33 to 34 , approaching $4 \mu \mathrm{g}$ chl- $a \mathrm{~L}^{-1}$.

In mid May 1992, 1993, and 1994 (figure 3e), the highest values of the year ( $>5 \mu \mathrm{g}$ chl- $a \mathrm{~L}^{-1}$ ) were reached, these high concentrations being distributed in a wide range of salinity, from 30 to 33.5 (plume waters). In late July 1993 (figure $3 g$ ), a highly significant correlation was established between chl- $a$ and salinity $(\mathrm{p}<0.001)$, showing high values of chlorophyll- $a$ in waters of salinity 26 $\left(4.5 \mu \mathrm{g} \mathrm{L}^{-1}\right)$, and a progressive decrease under $0.5 \mu \mathrm{g} \mathrm{L} \mathrm{L}^{-1}$ in marine waters.

\subsubsection{Bacterial distribution along the salinity gradient}

Throughout the year the abundance of bacteria was highest in estuarine waters (figure 4). Evolution of total numbers was closcly related to turbidity: significant correlations $(p<0.05)$ were established between total or attached abundance and turbidity or salinity, in almost all the seasons, indicating that bacteria would be associated essentially to estuarine particles discharged on the shelf. The dilution of big estuarine numbers is particularly clear prior to the spring bloom, reaching $10^{7}$ cell $\mathrm{mL}^{-1}$ in waters of salinity 22 and dropping generally to less than $2 \times$ $10^{6}$ cell $\mathrm{mL}^{-1}$ in marine waters (figure $4 b$ ). Even when phytoplankton spring bloom was well established in marine waters ('inner-shelf spring bloom'), bacterial abundance decreased from $8 \times 10^{6}$ at salinity 19 to less than $3.5 \times 10^{6}$ cell $\mathrm{mL}^{-1}$ in waters of salinity $>30$ (figure $4 d$ ).

In mid and advanced-spring, even though bacterial numbers of $4 \times 10^{6}$ cell mL $\mathrm{m}^{-1}$ were characteristic of estuarine waters, a dilution relationship was still highly significant in May 1994 (figure 4e). Plume and marine values were mainly under $10^{6}$ cell $\mathrm{mL}^{-1}$, except in the spring-summer transition, when plume waters showed seasonal maxima.
A.O. counts (1992) were in any case over the range of other year values, specially with deep samples (marine waters).

Finally, when considering the estuarine summer bloom period (figure $4 \mathrm{~g}$ ), a significant inverse correlation could be established between bacterial numbers and salinity, as demonstrated for chl- $a$ concentrations $(p<0.01)$.

\subsection{Microbial mean biomasses evolution in surface waters}

A general pattern of seasonal variability was deduced for each type of water, by considering only surface values, in order to avoid differences in depth sampling strategy. The author assembled different year patterns corresponding to a pre-defined seasonal situation. The results are illustrated in table II and figure 5, showing the distribution of mean parameters per season.

In marine shelf waters, both microalgae and bacterial biomasses were higher during the spring period (May 1, figure 5-1). This annual maximum corresponded to more than $80 \%$ of non-degraded chlorophyll and to high values of bacterial abundance and mean cell volumes, with less than $1.5 \%$ of attached bacteria (table IIa). Bacterial$\mathrm{C} /$ phytoplankton-C ratio reached then $40 \%$. The lowest value of algae was found in July 1993, with the greatest relative proportion of bacteria $(133 \%)$. Means of bacterial Cell Volume (M.C.V.) showed bigger cells in warmer periods, especially in early summer ( $t a b l e ~ I l a$ ), while percentages of attached bacteria were almost $<10 \%$, outside of great estuarine input periods (winter).

In plume waters, phytoplankton biomass described a bimodal distribution with a first peak in early March, and an annual maximum in the advanced-spring period ('May 2'), representing then $78 \%$ of the sum of phaeopigments and chlorophyll- $a$ concentrations (\% chla/tot) (table IIa). Bacterioplankton presented maximum values in early spring and summer, just after algal blooms. The first bacterial peak (comprising $37 \%$ of attached bacterial cells) corresponded to the lowest values of algae and represented then, in terms of biomass, twice the algae stock (figure 5-2). Bacterial-C represented only $32 \%$ compared to algal biomass in the spring-summer transition, and comprised only $5 \%$ of attached bacteria. Plume waters showed a short range of variability in cell volumes (table $I I b$ ), and maxima were measured in spring and late spring, reaching almost $0.044 \mu^{3}$ cell $^{-1}$. Percentages of attached bacteria decreased to less than $10 \%$ at spring and summer. 

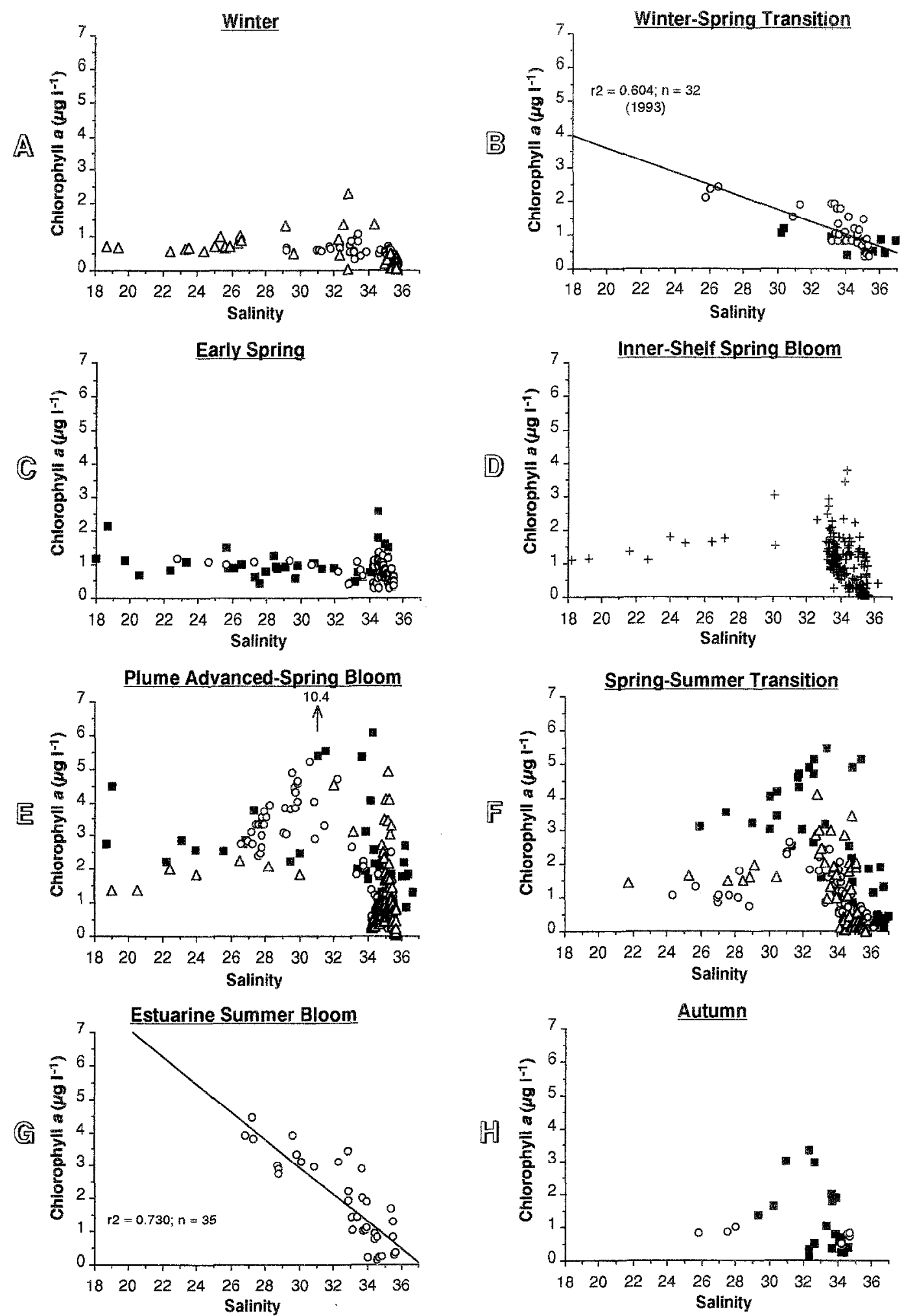

Figure 3. Seasonal distribution of chlorophyll- $a$ concentrations, on the Aquitanian shelf, along a saline gradient (the dilution plume of the Gironde estuary). 1992 (dark squares), 1993 (open circles), 1994 (open triangles), 1995 (crosses). 

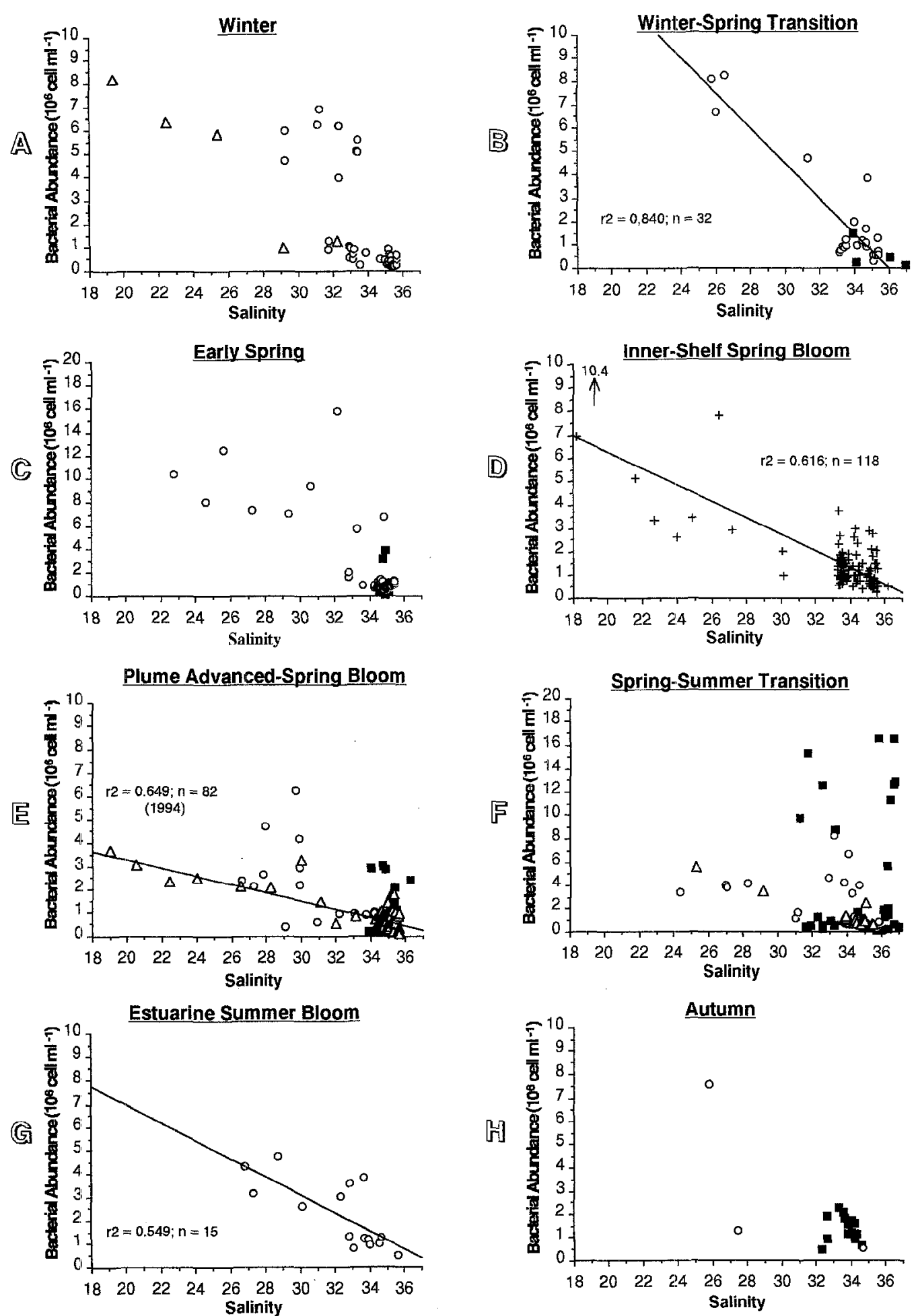

Figure 4. Seasonal distribution of bacterial abundance, on the Aquitanian shelf, along a saline gradient (the dilution plume of the Gironde estuary). Only the most significative correlations are drawn.

1992 (dark squares), 1993 (open circles), 1994 (open triangles), 1995 (crosses). 
In coastal estuarine waters, phytoplankton stocks followed a three-modal distribution, showing a first rise in early March 1993 corresponding to $62 \%$ of nondegraded chlorophyll, a second peak in late spring, and an annual maximum averaging $200 \mu \mathrm{g} \mathrm{C} \mathrm{L} \mathrm{C}^{-1}$ and $76.7 \%$ of chl-a/tot in the summer (table IIc). On the other hand, bacterial biomass during early spring reached values of
$100 \mu \mathrm{g} \mathrm{L} \mathrm{L}^{-1}$ representing nearly twice the algal stock (figure 5-3), and comprising $30.5 \%$ of attached bacteria. A stable distribution after the mid-spring period was observed, hacterial-C (hact-C) averaging from $25 \%$ in late spring and summer, to $50 \%$ and $100 \%$ compared to phytoplankton-C (phyto-C) in early summer and autumn. There was a low range of mean cell volumes in coastal

Table II a, b and c. Seasonal evolution of mean (S.D., $n$ ) values of different microbial patterns in surface waters, over the 4-year sampling period: chlorophyll- $a$, \% of chlorophyll-a/sum of degraded and non-degraded chlorophyll ('tot chl- $a$ Eq.'), bacterial abundance and mean cell volume (*only DAPI-staining bacterial measures were taken into account) and \% of attached bacterial cells. These measures were carried out in waters of salinity (Sal.) > 34 (Marine Shelf Waters); Sal. [30-34] (Plume Waters) and Sal. < 30 (Coastal Estuarine Waters). (A) Winter, (B) Winter-Spring Transition, (C) Early Spring, (D) Inner-Shelf Spring Bloom, (E) Plume Advanced-Spring Bloom, (F) Spring-Summer Transition, (G) Estuarine Summer Bloom, (H) Autumn.

\begin{tabular}{|c|c|c|c|c|c|}
\hline $\begin{array}{c}\text { Sal. > } 34 \\
\text { Surface Waters }\end{array}$ & $\begin{array}{l}\text { Chl-a } \\
\mu \mathrm{g} \mathrm{L} \mathrm{L}^{-1}\end{array}$ & $\begin{array}{c}\% \text { Chl- } a \text { /tot } \\
\text { chl-a Eq. }\end{array}$ & $\begin{array}{l}\text { Bacterial Abundance } \\
10^{6} \text { cell } \mathrm{mL}^{-1}\end{array}$ & $\begin{array}{c}\text { Mean cell volume* } \\
\mu^{3}\end{array}$ & $\begin{array}{c}\% \text { Attached } \\
\text { bacteria }\end{array}$ \\
\hline$A$ & $\begin{array}{c}0.42(0.17) \\
19\end{array}$ & $\begin{array}{c}62.7(10.0) \\
19\end{array}$ & $\begin{array}{c}0.38(0.12) \\
10\end{array}$ & $\begin{array}{c}0.023(0.002) \\
7\end{array}$ & $\begin{array}{c}26.2(10.8) \\
10\end{array}$ \\
\hline$B$ & $\begin{array}{c}0.65(0.22) \\
6\end{array}$ & $\begin{array}{c}67.2(9.1) \\
6\end{array}$ & $\begin{array}{c}0.80(0.71) \\
5\end{array}$ & $\begin{array}{c}0.030(0.004) \\
5\end{array}$ & $\begin{array}{c}18.2(12.3) \\
5\end{array}$ \\
\hline$C$ & $\begin{array}{c}0.89(0.30) \\
25\end{array}$ & $\begin{array}{c}70.1(9.9) \\
25\end{array}$ & $\begin{array}{c}1.23(1.65) \\
14\end{array}$ & $\begin{array}{c}0.029(0.007) \\
14\end{array}$ & $\begin{array}{c}7.8(9.7) \\
14\end{array}$ \\
\hline$D$ & $\begin{array}{c}1.25(0.48) \\
6\end{array}$ & $\begin{array}{c}81.1(6.5) \\
6\end{array}$ & $\begin{array}{c}1.81(1.07) \\
4\end{array}$ & $\begin{array}{c}0.044(0.002) \\
3\end{array}$ & $\begin{array}{c}1.4(0.5) \\
4\end{array}$ \\
\hline$E$ & $\begin{array}{c}1.00(0.73) \\
43\end{array}$ & $\begin{array}{c}76.7(8.5) \\
43\end{array}$ & $\begin{array}{c}0.74(0.59) \\
26\end{array}$ & $\begin{array}{c}0.039(0.008) \\
15\end{array}$ & $\begin{array}{c}3.5(5.7) \\
26\end{array}$ \\
\hline$F$ & $\begin{array}{c}0.69(0.81) \\
33\end{array}$ & $\begin{array}{c}62.6(8.9) \\
33\end{array}$ & $\begin{array}{c}0.91(0.70) \\
21\end{array}$ & $\begin{array}{c}0.052(0.011) \\
13\end{array}$ & $\begin{array}{c}15.3(13.9) \\
2 l\end{array}$ \\
\hline$G$ & $\begin{array}{c}0.18 \\
2\end{array}$ & $\begin{array}{c}71.1 \\
2\end{array}$ & $\begin{array}{c}1.00 \\
2\end{array}$ & $\begin{array}{c}0.034 \\
2\end{array}$ & $\begin{array}{c}0.6 \\
2\end{array}$ \\
\hline$H$ & $\begin{array}{c}0.52(0.23) \\
9\end{array}$ & $\begin{array}{c}65.2(10.7) \\
9\end{array}$ & $\begin{array}{c}1.10(0.41) \\
8\end{array}$ & $\begin{array}{c}0.039 \\
I\end{array}$ & $\begin{array}{c}9.4(6.1) \\
8\end{array}$ \\
\hline $\begin{array}{c}\text { Sal. }[30-34] \\
\text { Surface Waters }\end{array}$ & $\begin{array}{l}\text { Chl-a } \\
\mu g L^{-1}\end{array}$ & $\begin{array}{c}\% \text { Chl- } a \text { /tot } \\
\text { chl- } a \mathrm{Eq} .\end{array}$ & $\begin{array}{l}\text { Bacterial Abundance } \\
10^{6} \text { cell } \mathrm{mL}^{-1}\end{array}$ & $\begin{array}{l}\text { Mean cell volume } \\
\mu^{*}\end{array}$ & $\begin{array}{c}\text { \% Attached } \\
\text { bacteria }\end{array}$ \\
\hline$A$ & $\begin{array}{c}0.69(0.32) \\
12\end{array}$ & $\begin{array}{c}59.3(15.5) \\
12\end{array}$ & $\begin{array}{c}2.18(2.29) \\
9\end{array}$ & $\begin{array}{c}0.026(0.004) \\
9\end{array}$ & $\begin{array}{c}40.0(18.8) \\
9\end{array}$ \\
\hline$B$ & $\begin{array}{c}1.33(0.49) \\
13\end{array}$ & $\begin{array}{c}66.0(10.6) \\
13\end{array}$ & $\begin{array}{c}1.49(1.44) \\
7\end{array}$ & $\begin{array}{c}0.032(0.003) \\
6\end{array}$ & $\begin{array}{c}15.0(13.8) \\
7\end{array}$ \\
\hline$C$ & $\begin{array}{c}0.78(0.24) \\
9\end{array}$ & $\begin{array}{c}56.3(14.8) \\
9\end{array}$ & $\begin{array}{c}6.69(6.13) \\
5\end{array}$ & $\begin{array}{c}0.032(0.004) \\
5\end{array}$ & $\begin{array}{c}36.7(13.1) \\
5\end{array}$ \\
\hline$D$ & $\begin{array}{c}1.45(0.66) \\
22\end{array}$ & $\begin{array}{c}76.4(5.6) \\
22\end{array}$ & $\begin{array}{c}1.24(0.61) \\
11\end{array}$ & $\begin{array}{c}0.044(0.011) \\
11\end{array}$ & $\begin{array}{c}3.0(4.5) \\
11\end{array}$ \\
\hline$E$ & $\begin{array}{c}3.61(2.20) \\
16\end{array}$ & $\begin{array}{c}77.9(6.4) \\
16\end{array}$ & $\begin{array}{c}0.84(0.38) \\
8\end{array}$ & $\begin{array}{c}0.038(0.007) \\
7\end{array}$ & $\begin{array}{c}6.4(6.8) \\
8\end{array}$ \\
\hline$F$ & $\begin{array}{c}2.50(1.16) \\
36\end{array}$ & $\begin{array}{c}64.4(8.9) \\
36\end{array}$ & $\begin{array}{c}2.82(4.07) \\
19\end{array}$ & $\begin{array}{c}0.039(0.007) \\
9\end{array}$ & $\begin{array}{c}15.2(15.5) \\
19\end{array}$ \\
\hline$G$ & $\begin{array}{c}1.81(0.81) \\
9\end{array}$ & $\begin{array}{c}74.5(3.7) \\
9\end{array}$ & $\begin{array}{c}1.53(0.87) \\
5\end{array}$ & $\begin{array}{c}0.036(0.005) \\
5\end{array}$ & $\begin{array}{c}4.4(1.5) \\
5\end{array}$ \\
\hline$H$ & $\begin{array}{c}1.52(1.10) \\
13\end{array}$ & $\begin{array}{c}66.3(7.7) \\
13\end{array}$ & $\begin{array}{c}1.51(0.61) \\
8\end{array}$ & - & $\begin{array}{c}13.7(10.3) \\
8\end{array}$ \\
\hline
\end{tabular}


MICROBIAL BIOMASSES IN THE GIRONDE PLUME

\begin{tabular}{|c|c|c|c|c|c|}
\hline $\begin{array}{c}\text { Sal. }<30 \\
\text { Surface Waters }\end{array}$ & $\begin{array}{l}\mathrm{Chl}-a \\
\mu \mathrm{g} \mathrm{L} \mathrm{L}^{-1}\end{array}$ & $\begin{array}{l}\% \text { Chl- } a \text { /tot } \\
\text { chl- } a \mathrm{Eq} .\end{array}$ & $\begin{array}{l}\text { Bacterial Abundance } \\
10^{6} \text { cell } \mathrm{mL}^{-1}\end{array}$ & $\begin{array}{l}\text { Mean cell volume } \\
\mu^{*}\end{array}$ & $\begin{array}{c}\% \text { Attached } \\
\text { bacteria }\end{array}$ \\
\hline$A$ & $\begin{array}{c}0.76(0.25) \\
9\end{array}$ & $\begin{array}{c}43.5(17.6) \\
9\end{array}$ & $\begin{array}{c}5.22(2.70) \\
5\end{array}$ & $\begin{array}{c}0.027(0.004) \\
5\end{array}$ & $\begin{array}{c}45.8(19.8) \\
5\end{array}$ \\
\hline$B$ & 2.12 & 61.8 & 8.08 & 0.026 & 45.5 \\
\hline$C$ & $\begin{array}{c}1.06(0.37) \\
22\end{array}$ & $\begin{array}{c}48.4(13.3) \\
22\end{array}$ & $\begin{array}{c}9.11(2.32) \\
5\end{array}$ & $\begin{array}{c}0.028(0.002) \\
5\end{array}$ & $\begin{array}{c}30.4(7.9) \\
5\end{array}$ \\
\hline$D$ & $\begin{array}{c}1.45(0.29) \\
8\end{array}$ & $\begin{array}{c}75.7(7.5) \\
8\end{array}$ & $\begin{array}{c}5.32(2.81) \\
8\end{array}$ & - & $\begin{array}{c}46.1(16.7) \\
8\end{array}$ \\
\hline$E$ & $\begin{array}{c}2.91(0.91) \\
27\end{array}$ & $\begin{array}{c}68.5(13.6) \\
27\end{array}$ & $\begin{array}{c}2.93(1.47) \\
12\end{array}$ & $\begin{array}{c}0.033(0.003) \\
9\end{array}$ & $\begin{array}{c}29.4(8.9) \\
12\end{array}$ \\
\hline$F$ & $\begin{array}{c}1.96(0.99) \\
15\end{array}$ & $\begin{array}{c}63.6(8.6) \\
15\end{array}$ & $\begin{array}{c}4.08(0.88) \\
5\end{array}$ & $\begin{array}{c}0.037(0.007) \\
5\end{array}$ & $\begin{array}{c}28.3(17.5) \\
5\end{array}$ \\
\hline$G$ & $\begin{array}{c}3.82(0.60) \\
4\end{array}$ & $\begin{array}{c}76.7(1.4) \\
4\end{array}$ & $\begin{array}{c}4.57 \\
2\end{array}$ & $\begin{array}{c}0.036 \\
2\end{array}$ & $\begin{array}{c}16.6 \\
2\end{array}$ \\
\hline$H$ & $\begin{array}{c}1.02(0.31) \\
3\end{array}$ & $\begin{array}{c}46.5(3.6) \\
3\end{array}$ & $\begin{array}{c}4.41 \\
2\end{array}$ & $\begin{array}{c}0.032 \\
2\end{array}$ & $\begin{array}{c}44.4 \\
2\end{array}$ \\
\hline
\end{tabular}

waters, the maximum values corresponding to the warmer periods of June and July (table IIc). Percentages of attached bacteria were always $>15 \%$ (summer lowest values).

\subsection{Size distribution of phytoplankton and morpho- logy of bacteria over seasons}

Qualitatively, the chlorophyll maxima observed consecutively in marine, plume and estuarine waters corresponded to different cellular sizes [5]. At the beginning of the spring, picoplanktonic forms represented more than $70 \%$ of the total algae biomass in surface waters [57] and their importance decayed in the advanced spring period, while microplanktonic forms sensu stricto averaged $60 \%$ of the total biomass in plume waters. In estuarine waters, nanoplanktonic forms represented $60 \%$ of the total biomass in spring, whereas prior to summer bloom period, microplanktonic forms averaged $65 \%$ of the algal biomass.

Expressed only as a percentage of free bacterial numbers (attached forms could not be clearly separated into different forms), coccoid forms of small cellular mean volume $\left(0.025 \mathrm{\mu m}^{3}\right)$ were the dominating morphology in the three types of waters [5], especially in winter $(70 \%)$. Their importance decreased, especially in marine and plume waters, in the spring bloom period, when vibrioshaped forms (of annual average volumes of 0.052 and $0.049 \mu^{3}$, respectively) represented almost a third of the total abundance. Finally, rod-shaped bacteria, of average annual volumes of 0.051 (marine waters) and $0.049 \mu^{3}$ cell $^{-1}$ (plume waters) were better represented in the advanced-spring bloom, reaching a maximum in plume waters $(22 \%)$. This cycle could not be characterised in estuarine waters, that showed important percentages of coccoid forms all over the year, and an increasing importance of vibrio-shaped forms, in summer and fall (19\% and $25 \%$, respectively). Rod-shaped bacteria averaged bigger cellular volumes $\left(0.056 \mu \mathrm{m}^{3} \mathrm{cell}^{-1}\right)$ than in both other water types.

\section{DISCUSSION}

\subsection{Bacteria-phytoplankton correlations obtained on the basis of single values}

All of the last 3-year data on bacterial counts (determined with DAPI fluorescent dye) seems to be weakly determined by chlorophyll- $a$ (only $17 \%$ of the total variance having been explained by this regression model, figure 6). As measures carried out in this study were centred on the $1 \mu \mathrm{g}$ chl- $a . \mathrm{L}^{-1}$ level, we did not actually cover the wide range of concentrations described in literature reviews (including eutrophic systems). On the other hand, our $\left[2 \times 10^{5}-1.6 \times 10^{7}\right.$ cell $\left.\mathrm{mL}^{-1}\right]$ bacterial range corresponded to lower [13] and upper [3] values of bacterial abundance usually measured in marine systems. The calculated regression coefficient $(0.39)$ was much closer to that found in Cole et al. [16] general review (0.52), than to that calculated by Bird and Kalff [11] in marine waters (0.74). Nevertheless, due to the low determination coefficient obtained in this study, the Model II [42] regression coefficient of 0.95 was more accurate when making this comparison. In fact, the data were not corrected, nor aver- 

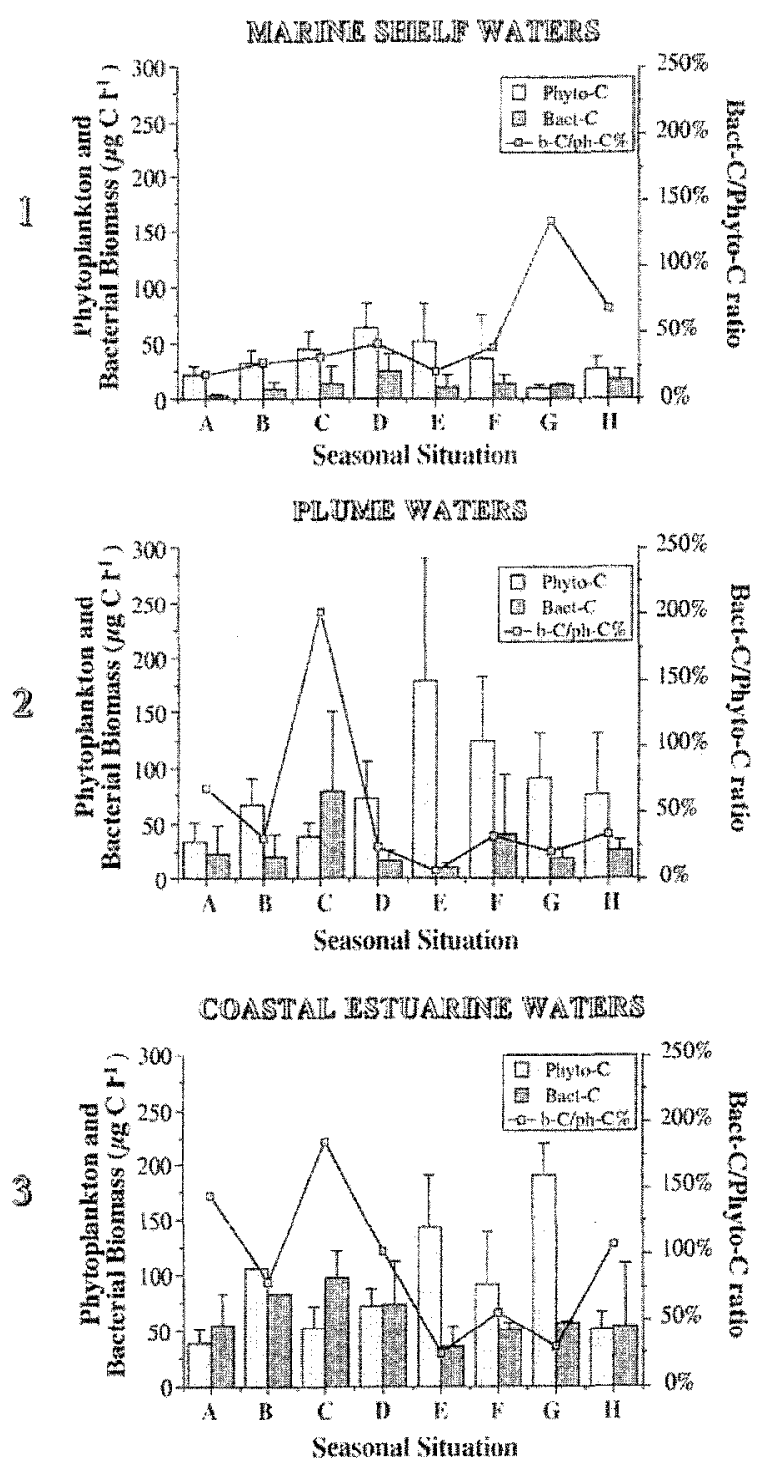

Figure 5. Evolution of per-season mean phytoplankton (phyto-C) and bacterial (bact-C) biomasses ( \pm S.D.), and seasonal variability of bacterial-C/phytoplankton-C (b-C/ph-C) mean ratio: (1) in marine shelf waters (salinity $>34$ ), (2) plume waters (salinity [ 30 341), and (3) coastal estuarine waters (salinity < 30). (A) Winter, (B) Winter-Spring Transition, (C) Early Spring, (D) Inner-Shelf Spring Bloom, (E) Plume Advanced-Spring Bloom, (F) SpringSummer Transition, (G) Estuarine Summer Bloom, (H) Autumn.

aged per water masses, and that might have led to these differences.

The determination of the general correlation was however improved when taking into account the degraded pigment fraction (phaeopigments): the model accounted for $34 \%$ of the whole variance. This relationship outlines the importance of the detritic part of phytoplanktonic stock

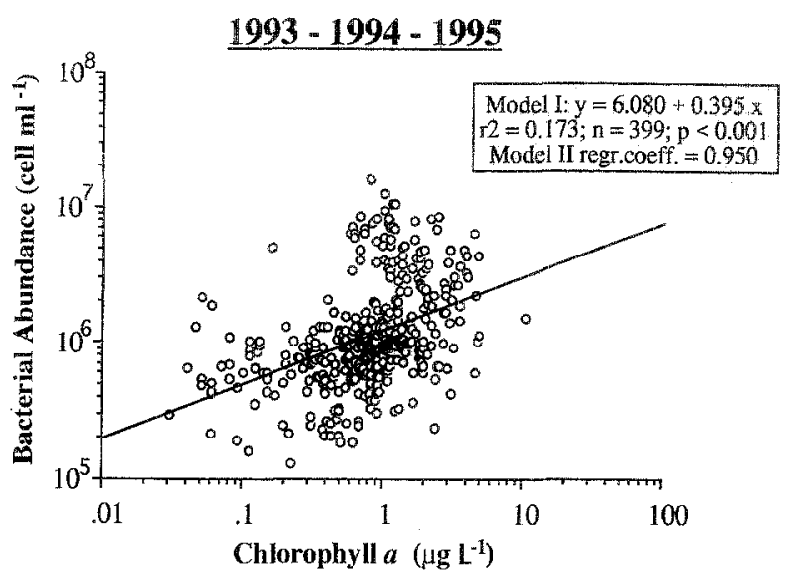

Figure 6. Distribution patterns and calculated correlation model (Model I) of log-transformed bacterial abundance and chlorophyl$a$ data over the last 3 years sampling period on the Aquitanian shelf (only DAPI bacterial counts were taken into account). Pearson's determination coefficient and significance $\left(r^{2}, n, p\right)$. Model II regression coefficient (regr. coeff.).

discharged by the estuary as detritic pigments, or degraded on the shelf (grazing, cellular lysis, decay), as a major mode of transfer between algae and heterotrophic bacteria [38].

Simon et al. [61] reported that relationships on a biomass basis emphasize other different aspects of the structure of pelagic food webs than cell numbers and chlorophyll- $a$. Notwithstanding a weak general correlation calculated on a biomass basis $\left(r^{2}=0.166\right)$, some seasonally significant correlations seemed to be improved with rising temperatures, coinciding with bloom periods (figure 7): the regression coefficient (Model II) ranged between 0.24 and 0.26 in marine and plume waters (May 1995) and in all water types (late May and July 1993). This slope was close to that calculated by Simon et al. [61] (0.23), on marine microbial biomasses. In the summer, when the regression model was particularly explanatory, the detritic particle amount was low in the mouth of the Gironde, corresponding to the low water level, and the attached bacteria averaged minimal proportions throughout the entire plume shelf system. It seems that outside of great estuarine input periods, bacterial-C represents a mean proportion of $25 \%$ compared to phytoplankton-C.

\subsection{Relative importance of bacterial carbon}

High and low bact/phyto C-ratios indicate fundamental differences in the food-web structure in oligotrophic and eutrophic ecosystems [22]. The increasing dominance of 

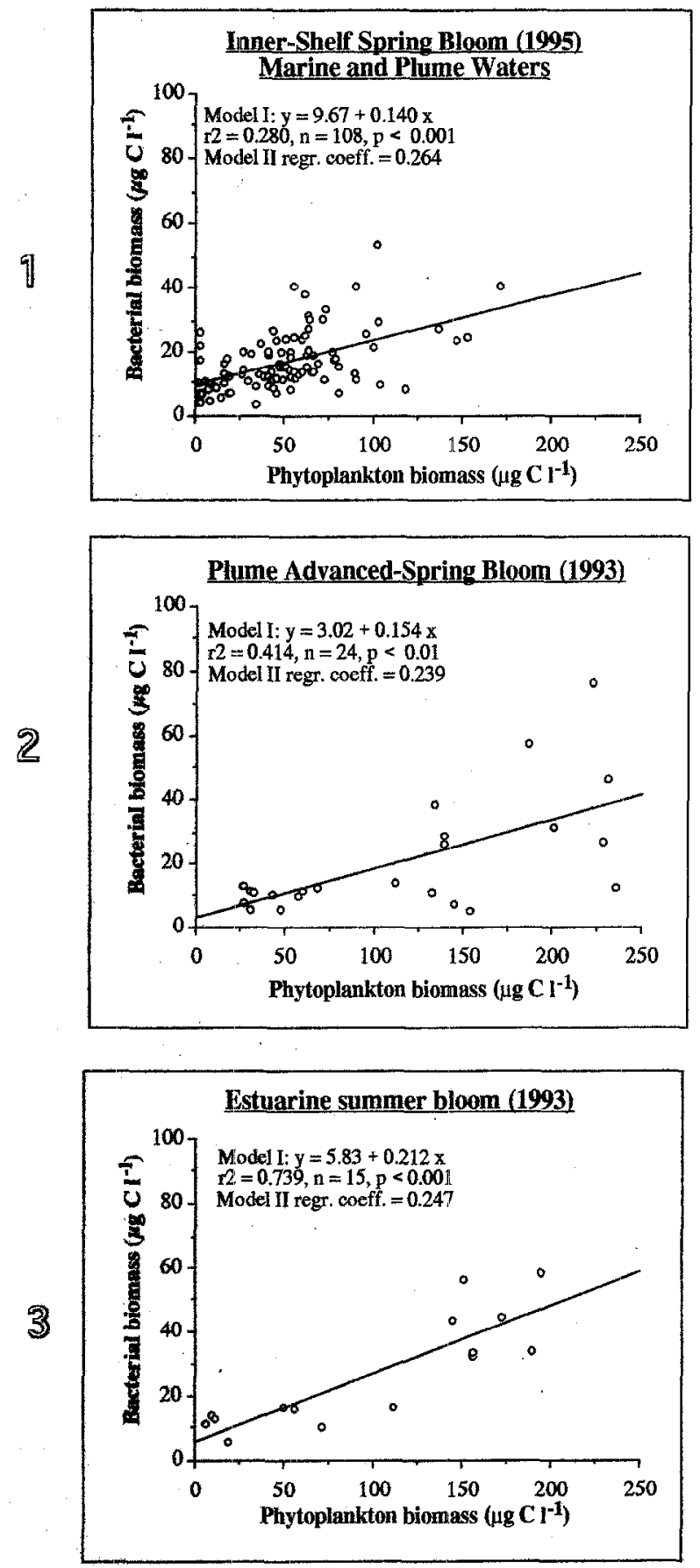

Figure 7. Relative importance of bacterioplankton biomass related to phytoplankton biomass: three of the most significant seasonal relationships obtained over the 4-year sampling period, in the Aquitaniarı shelf. Correlation model (Model I) of microbial biomass data, Pearson's determination coefficient and significance $\left(r^{2}, n\right.$, p). Model II regression coefficient (regr. coeff.). (1) Inner-Shelf Spring Bloom, (2) Plume Advanced-Spring Bloom, (3) Estuarine Summer Bloom heterotrophic and autotrophic picoplankton and the importance of the 'microbial loop' [6], in high bacterial/ phytoplankton carbon ('microbial-C ratio') periods, attributable to oligotrophic conditions [61], is in contrast with low ratios as the autotrophic and heterotrophic picoplankton become less important with increasing trophic state. The Gironde plume and the Aquitanian inner shelf showed in effect large seasonal variations in this microbial-C ratio. By taking into account a rapid bloom limitation in mid-spring [32], the size structure of the phytoplankton community in spring [57] and the magnitude of the sedimentary organic fluxes [41], we can deduce that this ecosystem is actually a mesotrophic ecosystem [55] with large seasonal variations covering major oligotrophic and less frequent eutrophic situations, with a fairly variable foodweb structure.

General seasonal patterns of variability for both microbial mean values in surface waters were defined in three different types of environment. These three water types displayed a really different seasonal evolution of microbial biomasses and morphometrical composition of bacteria and phytoplankton. Two main separate trends were distinguished: while the microbial- $\mathrm{C}$ ratio became progressively higher during the course of the seasons in marine waters, the greatest ratios, on the contrary, characterized winter and early spring periods in brackish waters, in accordance with high estuarine expulsion periods.

\subsection{Importance of microbial- $C$ in the particulate organic pool}

When considering bacterial and phytoplankton relative importance in the particulate organic carbon (POC) pool, Cho and Azam [13] noticed that, for POC values under $200 \mu \mathrm{g} \mathrm{l}^{-1}$, the sum of bacterial and phytoplankton carbon ('microbial-C') represented roughly $50 \%$ of the POC, in oligotrophic and mesotrophic marine waters, and that bacterial-C was never less than $14 \%$ of the POC. During the present study, such low POC concentrations were found only in marine waters. Even though there was not a highly significant relationship between microbial-C and POC at surface levels, bact-C plus phyto-C sum represented almost $41 \%$ of the POC $(10 \%$ and $30 \%$ respectively) in the three spring periods, which is comparable to Cho and Azam [13] estimation. In brackish waters, the relative importance of bacteria showed a wide range of variability. As POC concentrations were high in early spring, bact-C represented up to $27 \%$ of the POC. When POC mean values exceeded $700 \mu \mathrm{g} \mathrm{L}^{-1}$ then the micro- 
bial-C represented less than $25 \%$ of the organic pool and, specially in the advanced-spring period, bacteria accounted for less than $5 \%$ of it. The organic pool was then mainly composed of refractory detritic carbon, in accordance with estimations made by Lin [44].

\subsection{Importance of the attachment of bacteria in a highly turbid environment}

In estuaries, the altached state can be either rare [49], predominant [30] or of a varying predominance depending on the season or the salinity. In the Gironde estuary, as in the Humber estuary, the principal mode of distribution of estuarine suspended particles (dry weight) is $<40 \mu \mathrm{m}$ ( 8 $10 \mu \mathrm{m}$, [69]), and attached bacteria represents up to $60 \%$ of the total bacterial numbers. These high proportions, corresponding mostly to the 'estuarine coastal waters', tended to decrease during the warmer periods, as it was noticed by Iriberri et al. [35] and by Almeida and Alcântara [2]. This state could be advantageous in natural environments [50], and protective against stress [31], but Loodsdrecht et al. [45] recently concluded that the diverse metabolic changes do not always follow a general increase in activity after bacterial adhesion. Bacterial adherence may be related to particle abundance [30], as was shown particularly in estuarine and plume waters in the present study, but it depends also on particle quality or shape [19].

Considering the important 'non-labile fraction' of the Gironde's organic pool (almost $>70 \%$ of the POC, [12]) and the relatively small size of the attached bacteria (an overall average cell volume of $0.029 \mu \mathrm{m}^{3} \pm 0.013$, $\mathrm{n}=131$, in all situations and water types), one can infer there is a strong control of these attached cells by organic resources and by bacterivore protists. There is also a scarce autochtonous organic production in this environment limited by high turbidity [37]. In spite of its important total amounts of dissolved and particulate organic matter, the Gironde estuary does not allow continental inputs to pass through the maximum turbidity zone (>200 $\mathrm{mg} \mathrm{SPM} \mathrm{L}^{-1}$ ), which represents virtually a filter for 'fresh' organic compounds [36].

\subsection{Controlling factors of bacterial biomass}

Apart from being influenced by physical and chemical factors (temperature, $\mathrm{pH}$ and solar radiation), bacteria are controlled by 'bottom-up', as well as by 'top-down' forces
[10]. The relative importance of bacteria in estuarine and plume waters, compared to marine waters, may point out the fact that allochtonous substrate sources in addition to primary production lead to an enhanced biomass and production of bacteria. Baines and Pace [7] noticed that in most aquatic systems, over half of the bacterial carbon requirement is met by sources other than phytoplankton extracellular release: allochtonous $\mathrm{C}$ sources coming from estuarine inputs, sloppy feeding, zooplankton excretion and also phytoplankton senescence are required to balance bacterial needs.

As none of these processes, nor extracellular release, seem to be primarily related to phytoplankton biomass, it was not surprising that direct highly significant general correlations between bacterial and phytoplankton biomasses were not obtained. A better correlation appeared when considering degraded pigments, favouring a better indirect bacterial-phytoplankton dependence. Nevertheless, these degraded pigments were not systematically correlated to POC in spring, neither did bacterial biomass, considering different water type values. The strong and constant correlation found between bacterial numbers and suspended particulate matter suggest that this environment might have favoured bacterial attachment and accumulation, independently of trophic regulations. Shiah and Ducklow [59] argued that, in estuarine habitats, temperature appears to play a more important role than substrate supply in regulating bacterial growth. As a matter or fact, it seems that hydrodynamic conditions, associated with summer warming (low turbidity period), lead to phytoplankton and free-bacterial development in brackish waters.

Bacterivores, recognizing strong differences in bacterial populations (sizes and morphotypes), are also supposed to control their prey in different ways in brackish and marine waters.

\subsection{Significance and importance of seasonal micro- bial morphometrical variability}

\subsubsection{Inter-spring phytoplankton size distribution}

The relative importance of large vs. small phytoplankton is actually highly variable in shelves [65], especially in an area submitted to the influence of a dilution plume. Our results, that concern only different spring periods, showed that in marine waters, microphytoplankton sensu stricto seemed to thrive within a relatively narrow range 
of hydrological conditions, whereas pico- and nano-phytoplankton dominated the pool of algal cells. In plume and estuarine waters, phytoplankton was dominated successively by pico-, nano- and, closer to the early summer period, larger microplanktonic forms, reproducing clear differences among seasons throughout different water masses. Tremblay et al. [66] consider that small phytoplankton provides a steady state background of production and biomass whereas large phytoplankton is responsible for departures from the background. According to this, larger cells representing an average of more than $60 \%$ of the total phytoplankton could characterize the beginning of the advanced-spring bloom (in plume waters) and the beginning of the summer bloom (in estuarine waters).

\subsubsection{Seasonal evolution of bacterial forms}

The seasonal morphotype succession caused changes in mean cell volumes which could have more or less influenced the general patterns of biomass evolution, mainly ruled by bacterial numbers. Across the seasons, estuarine bacteria showed the lowest mean volume due to high proportions of attached and coccoid cells in its population. Nevertheless, a small increase on estuarine cell volumes was noticed in late spring and summer periods, in accordance with an increased proportion of vibrio-shaped and rod-shaped cells (representing then $25 \%$ of free bacterial biomasses, [5]). In plume waters, attached and coccoid cells dominated the bacterial pool in winter and spring, whereas in summer a relative increase in rodshape and vibrio-shaped cells was observed (representing respectively $23 \%$ and $29 \%$ of free bacterial biomass). Finally, in marine waters seasonal changes in biomass were much more pronounced between the winter and the spring periods $(\times 7)$ : the rise in abundance values was enhanced by a doubling of the global mean cell volume, due to the rising importance of much bigger vibrioshaped cells (representing $40 \%$ of the total biomass).

\subsubsection{Consequences of bacterial size distribution}

The dominance of relatively small bacterial cells (mean cell volumes $<0.100 \mu \mathrm{m}^{3}$ ) throughout this study, compared to other coastal and estuarine studies, seems to be a general feature in marine and freshwater pelagic systems. Although bacterial cell sizes often cannot be directly predicted from abiotic factors alone [52], Albright and McCrae [1] have, however, associated great decreases in bacterial cell size with cold seasons, as it has been pointed in the present study. The important pool of very small cells (small coccoid forms of $<0.033 \mu \mathrm{m}^{3}$ ) may constitute a refuge (bacteria being able to escape predation), Jürgens and Güde [39] having recently predicted the formation of grazing-resistant bacterial morphotypes during intense protist predation, but at the same time it may represent a state of low physiological turnover [29].

It can be inferred that the smallest bacterial cells, representing high percentages especially in winter and earlyspring throughout the entire system 'estuary-plume-innershelf', were only marginally involved in growth and predation processes. It would be too speculative, however, to assign bacterial activity only to one size fraction, even when in their work Pernthaler et al. [52] have noticed that there is a positive correlation between changes in the bacterial biomass in the average $0.045 \mu \mathrm{m}^{3}$ size class and per-cell thymidine uptake. Not dead but 'dormant' bacterial cells can represent an average of more than $60 \%$ of total bacterial counts, according to Sherr and Sherr [58], considering estimations of metabolically active bacteria by the detection of radiolabelled substrates [51], or by indication of an active electron transport system [56].

\section{CONCLUSION}

Studies of the relationships between bacterio- and phytoplankton biomass are relatively scarce in literature: Simon et al. [61], seemed to be some of the first to establish such a comparison, in which at least the C/cell volume ratio of bacteria was taken into account. Even though our study cannot be compared to longer reviews because of its limited spatial cover, it appears to be one of the first comparisons related to high turbid coastal waters and phosphorus-limited marine systems. Two large tendencies can be deduced from it:

- firstly, when a significant relationship is noted between bacterial-C and phytoplankton- $\mathrm{C}$, the regression coefficient is close to 0.25 , meaning a relatively low participation of bacteria, specially during bloom periods.

- in chlorophyll-poor waters (deep-shelf samples), as well as in environments with a large detrital pigment proportion (estuarine samples), bacterial-C has a great importance and microbial-C ratio can vary independently from chlorophyll values. Notwisthstanding an important detritical organic fraction, the poor nutritional quality of the POC [12] contrasts with the strong bacterial attachment, in estuarine waters. In fact, the relative 
invariability of bacterial numbers (low numbers in deep marine waters, or constantly high abundance in estuarine numbers), would mask other processes within bacterial assemblages that are relative to hacterial growth and production [20]. On the other hand, it may be that bacterivore populations are too low to exert a strong predation pressure in estuarine waters, or that they do not feed efficiently below cell volumes $<0.033 \mu \mathrm{m}^{3},[52]$, and below $2 \times 10^{5}$ cell $\mathrm{mL}^{-1}[13]$, in deep marine waters.

It is generally admitted that phytoplankton is dominant at coastal zones. However, in this study, the importance of heterotrophic carbon was pointed out in a coastal and shelf ecosystem influenced by a highly-turbid estuary. Both phyto- and bacterioplankton represented in surface levels almost $1 / 2$ to $1 / 4$ of the POC in marine and plume waters, whereas in coastal estuarine waters this proportion reached only $1 / 10$ (high detritic fraction). The bacterial/phytoplankton-C-mean ratio was high in the plume in winter and in spring, in accordance with great estuarine expulsions; bacterial-C represented, then, one or two times the phytoplanktonic biomass, composed mainly of picoplanktonic forms. During bloom periods, microphytoplankton sensu stricto rose relatively to more than $50 \%$ of the total algal biomass, and the bact-C/phyto- $\mathrm{C}$ ratio reached its lowest values of the year. In fact, according to Riegman et al. [55], picoplanktonic forms characterize primary production-limited systems ('maintenance systems'), while large cells are common in 'over-flow' systems. As the Aquitanian inner shelf seems to be rapidly limited by phosphate concentrations in spring [32], with low vertical fluxes [41], high microbial-C ratios represent increased 'microbial loop' processes [6].
Thus, even though the relative importance and the variability of bacterial and phytoplankton carbon can give a good idea of the state and evolution of shelf systems, the determination of metabolically active bacteria, coupled with a further study of bacteria and phytoplankton production over seasons, seems indispensable for a better understanding of microbial dynamics and their fate in this complex shelf ecosystem.

\section{Acknowledgments}

This study was supported by the ECOMARGE, PNTS and PNOC programmes, and by their local co-ordinators: O. Weber and J.-M. Froidefond (D.G.O., UMR 5805), and P. Laborde (L.O.B., UMR 5805). J.-M. Froidefond, J.E. Hermida and J.-M. Jouanneau (D.G.O., UMR 5805) kindly provided me with some of the data on temperature, salinity and suspended particulate matter for the area studied, as did B. Boutier and P. Michel of the LCCM-IFREMER Laboratory. I also thank D. Delmas for making available his unpublished data on POC. I would like to specially thank Dr. Laborde for his invaluable help in organising and discussing strategies and results for this study, and P. Caumette (L.O.B. director) for providing the logistics for bacterial measures. I am specially indebted to the crews of the different research ships, for their precious help and express my gratitude towards both anonymous reviewers for their constructive observations and advices. This Ph.D. work was directly supported by a co-operation grant from the French Government.

\section{REFERENCES}

[1] Albright L.J., McCrae S.K., Annual cycle of bacterial specific biovolumes in howe sound, a Canadian West Coast Fjord Sound, Appl. Environ. Microbiol. 53 (12), (1987) 2739-2744.

[2] Almeida M.A., Alcântara F., Bacterial colonization of seston particles in brackish waters (Ria de Aveiro, Portugal), Mar. Ecol. Prog. Ser. 89 (1992) 165-173.

[3] Andersen P., Sørensen H.M., Population dynamics and trophic coupling in pelagic microorganisms in eutrophic coastal waters, Mar. Ecol. Prog. Ser. 33 (1986) 99-109.

[4] Artigas L.F., Variabilité saisonnière des pigments chlorophylliens dans le Panache de Dilution de l'Estuaire de la Gironde dans le Plateau Continental Aquitain, in: IV Coloquio Internacional sobre Oceanografía del Golfo de Vizcaya, O. C.-I. Olaso (ed.), Santander (Spain) (1995) 19-28.

[5] Artigas L.F., Dynamique du compartiment microbien dans une aire néritique soumise à des apports continentaux importants
(Panache de dilution de la Gironde, sur le Plateau continental Aquitain). Thèse de Doctorat d'Université, Université Bordeaux I, (1997) $340 \mathrm{p}$.

[6] Azam F., Fenchel T., Field J.G., Gray J.S., Meyer-Reil L.A., Thingstad F., The ecological role of water-column microbes in the sea, Mar. Ecol. Prog. Ser. 10 (1983) 257-263.

[7] Baines S., Pace M.L., The production of dissolved organic matter by phytoplankton and its importance to bacteria: Patterns across marine and freshwater systems, Limnol. Oceanogr. 36, 6 (1991) 1078-1090.

[8] Banse K., Determining the carbon-to chlorophyll ratio of natural phytoplankton, Mar. Biol. 41 (1977) 199-212.

[9] Barthe X., Les suspensions dans les eaux du Plateau Continental du Golfe de Gascogne. Thèse de $3^{\text {e }}$ Cycle, Université de Bordeaux-I (1987) $197 \mathrm{p}$. 
[10] Billen G., Servais P., Becquevort S., Dynamics of bacterioplankton in oligotrophic and eutrophic aquatic environments: bottom-up or top-down control? Hydrobiologia 207 (1990) $37-42$.

[11] Bird D.F., Kalff J., Empirical relationships between bacterial abundance and chlorophyll concentration in fresh and marine waters, Can. J. Fish. Aquat. Sci. 41 (1984) 1015-1023.

[12] Burdloff D., Potentiel nutritif des particules et implications biologiques en milieu estuarien. Thèse de Doctorat d'Université, Université Bordeaux-I (1997) 207 p.

[13] Cho C.B., Azam F., Biogeochemical significance of bacterial biomass in the oceans euphotic zone. Mar. Ecol. Prog. Ser. 63 (1990) 253-259.

[14] Cho C.B., Choi J.-K., Chung CH.-S., Hong G.H., Uncoupling of bacteria and phytoplankton during a spring diatom bloom in the mouth of the Yellow Sea, Mar. Ecol. Prog. Ser. 115 (1994) $181-190$

[15] Coffin R.B., Sharp J.H., Microbial trophodynamics in the Delaware estuary, Mar. Ecol. Prog. Ser. 43 (1987). 1-10.

[16] Cole I.I., Findlay S., Pace M.L., Bacterial production in fresh and saltwater ecosystems: a cross-system overview, Mar. Ecol. Prog. Ser. 43 (1988) 1-10.

[17] Conover R.J., Durvasula R., Roy S., Wang R., Probable loss of chlorophyll-derived pigments during passage through the gut of zooplankton, and some of the consequences, Limnol.Oceanogr. 31,4 (1986) 878-887.

[18] Daley R.J., Hobbie J.E., Direct counts of aquatic bacteria by a modified epifluorescence technique, Limnol. Oceanogr. 20 (5) (1975) 875-882.

[19] De Flaun M., Mayer L., Relationships between bacteria and grain surfaces in intertidal sediments, Limnol. Oceanogr. 28, 5 (1983) $873-881$

[20] Del Giorgio P.A., Prairie Y.T., Bird D.F., Coupling between rates of bacterial production and the abundance of metabolically active bacteria in lakes, enumerated using CTC reduction and flow cytometry, Microb. Ecol. 34 (1997) 144-154

[21] De la Giraudière I., Chromatographie HPLC des chlorophylles et de leur dérivées. Application à des interfaces (ContinentOcéan; Air-Mer), Thèse de $3^{\mathrm{e}}$ cycle, Université d'AixMarseille II (1987) 125 p.

[22] Dortch Q., Packard 'T., Differences in biomass structure between oligotrophic and eutrophic marine ecosystems, Mar. Ecol. Prog. Ser. 63 (1989) 223-240

[23] Ducklow H.W., Kirchman D.L., Bacterial dynamics and distribution during a spring diatom bloom in the Hudson River plume, USA. J. Pl. Res. 5, 3, (1983) 333-335.

[24] Ducklow H.W., Shiah F.-K., Bacterial production in estuaries, in Aquatic Microbiology, T. E. Ford (eds.), Boston, Oxford, London, Edinburgh, Melbourne, Paris, Berlin, Vienna, Blackwcll Scientific Publications (1993) 261-287.

[25] Eppley R.W., Harrison W.G., Chisholm S.W., Stewart E., Particulate organic matter in surface waters off Southern California and its relationship to phytoplankton, J. mar. Res. 35 (1977) 671-696
[26] Ferguson R.L., Rublee P., Contribution of bacteria to standing crop of coastal plankton, Limnol. Oceanogr. 21 (1976) 141144.

[27] Fuhrman J.A., Ammerman J.W., Azam F., Bacterioplankton in the coastal euphotic zone: distribution, activity and possible relationships with phytoplankton, Mar. Biol. 60 (1980) 201-207.

[28] Garnier J., Barillier A., Synthèse et dégradation de la matière organique dans les écosystèmes aquatiques: boucle microbienne et statut trophique, Océanis 17, 5 (1991) 561-580.

[29] González J.M., Sherr E.B., Sherr B.F., Differential feeding by marine flagellates on growing versus starving and on motile versus nonmotile, bacterial prey, Mar. Ecol. Prog. Ser. 102 (1993) $257-267$

[30] Goulder R., Bent E.J., Boak A.C., Attachment to suspended solids as a strategy of estuarine bacteria, in Feeding and survival strategies of estuarine organisms, N.V.J. and. W.J. Wolff (eds.), Plenum Press (1981) 1-15.

[31] Harvey R.W., Lion L.W., Young L.Y., Leckie J.O., Enrichment and association of lead and bacteria at particulate surfaces in a salt-marsh surface layer, J. mar. Res. 40 (4) (1982) 1201-1212.

[32] Herbland A., Delmas D., Laborde P., Sautour B., Artigas F. The phytoplankton bloom of the Gironde plume waters in the Bay of Biscay: early phosphorus limitation and food-web consequences, in press Oceanol. Acta (1998).

[33] Hermida J.E., Dispersion des eaux estuariennes de la Gironde sur le Plateau Continental, Thèse de Doctorat d'Université, Université Bordeaux I (1997) 178 p.

[34] Hoch M.P., Kirchman D.L., Seasonal and inter-annual variability in bacterial production and biomass in a temperate estuary, Mar. Ecol. Prog. Ser. 98 (1993) 283-295.

[35] Iriberri J., Unanué M., Barcina I., Egea L., Seasonal variation of population density and heterotrophic activity of attached and free-living bacteria in coastal waters, Appl. Environ. Microbiol. 53 (10) (1987) 2308-2314.

[36] Irigoien X., Burdloff D., Castel J., Etcheber H., Light limitation and organic matter in estuarine systems: the role of the maximum turbidity zone controlling the quality of the organic matter, in IV Coloquio Internacional sobre Oceanografía del Golfo de Vizcaya , O.C.-I. Olaso (ed.), Santander (Spain) (1995) 55-63.

[37] Irignien X., Castel I., I ight limitation and distribution of chlorophyll pigments in a highly turbid estuary: the Gironde (SW France), Est. Coast. Sh. Sc. 44 (1997) 507-517.

[38] Jumars P.A., Penry D.L., Baross J.A., Perry M.J., Frost B.W., Closing the microbial loop: dissolved carbon pathway to heterotrophic bacteria from incomplete ingestion, digestion and absorption in animals. Deep-Sea Res. 36, 4 (1989) 483-495.

[39] Jürgens K., Güde H., The potential importance of grazingresistant bacteria in planktonic systems, Mar. Ecol. Prog. Ser. 112 (1994) 169-188.

[40] Kirchman D.L., Soto Y., Van Wambeke F., Bianchi M., Bacterial production in the Rhône River plume: effect of mixing on 
relationships among microbial assemblages, Mar. Ecol. Prog. Ser. 53 (1989) 267-275.

[41] Laborde P., Artigas L.F., Delmas D., Herbland A., Sautour B., Les flux de particules biogéniques à la base de la couche euphotique dans le panache de dilution de la Gironde (plateau continental français, Golfe de Gascogne): situations printanières. oral communication at the Ve Colloque International d'Océanographie du Golfe de Gascogne, La Rochelle (France) (1996).

[42] Laws E.A., Archie J.W., Appropiate use of regression analysis in Marine Biology, Mar. Biol. 65 (1981) 13-16.

[43] Lee S.H., Fuhrman L., Relationships between biovolume and biomass of naturally derived marine bacterioplankton, Appl. Environ. Micrub. 53, 6 (1987) 1298-1303.

[44] Lin R.G., Etude du potentiel de dégradation de la matière organique particulaire en passage eau doucc-eau salée : cas de l'estuaire de la Gironde. Thèse de Doctorat d'Université, Université Bordeaux I, (1988) 209 p.

[45] Loosdrecht M.C., Lyklema J., Norde W., Zehender A., Influence of interfaces on microbial activity, Microbiol. Rev. 54 (1), (1990) 75-87.

[46] Malone T.C., Ducklow H.W., Microbial biomass in the coastal plume of Chesapeake Bay: Phytoplankton-bacterioplankton relationships, Limnol. Oceanogr. 35, 2, (1990) 296-312.

[47] Nielsen T.G., Richardson K., Food chain structure of the North Sea plankton communities: seasonal variations of the role of the microbial loop, Mar Ecol. Prog. Ser. 56 (1989) 75-87.

[48] Norland S., The Relationship Between Biomass and Volume of Bacteria, in Handbook of methods in Aquatic Microbial Ecology, P.F. Kemp, Sherr B.F., Sherr E.B. and Cole J.J. (eds.), Boca Raton, Ann Arbor, London, Tokyo, Lewis Publishers (1993) 303-307.

[49] Painchaud J., Therriault J.-C., Relationships between bacteria, phytoplankton and particulate organic carbon in the Upper St. Lawrence Estuary, Mar. Ecol. Prog. Ser. 56 (1989) 301-311.

[50] Pedrós-Alió C., Brock T.D., The importance of attachment to particles for planktonic bacteria, Arch. Hydrobiol. 98 (1983) 354-379.

[51] Pedrós-Alió C., Newell S.Y.; Microautoradiographic study of thymidine upatake in brackish waters around Sapelo lsland, Georgia, USA, Mar. Ecol. Prog. Ser. 55 (1989) 83-94.

[52] Pernthaler J., Sattler B., Simek K., Schwarzenbacher A., Psenner R., Top-down effects on the size-biomass distribution of a freshwater bacterioplankton community, Aquat. Microb. Ecol. 10 (1996) 255-263.

[53] Porter K.G., Feig Y.S., The use of DAPI for identifyng and counting aquatic microflora, Limnol. Oceanogr. 25, 5 (1980) 943-948.

[54] Redalje D.G., Phytoplankton carbon biomass and specific growth rates determined with the labeled chlorophyll a technique,. Mar. Ecol. Prog. Ser. 11 (1983) 217-225.

[55] Riegman R., Kuipers B.R., Noordelos A.A.M., Witte H.J., Size-differential control of phytoplankton and the structure of plankton communities, Neth. J. Sea Res. 3 (1993) 255-265.
[56] Rodríguez G.G., Phipps D., Ishiguro K., Ridgway H.F., Use of a fluorescent redox probe for direct visualization of actively respiring bacteria, Appl.Environ.Microbiol. 58, 6 (1992) $1801-1808$.

[57] Sautour B., Artigas F., Herbland A., Laborde P., Zooplankton grazing impact in the plume of dilution of the Gironde estuary (France) prior to the spring bloom, J. Plankton Res. 18,6 (1996) 835-853.

[58] Sherr E.B., Sherr B.F., Temporal offset in oceanic production and respiration processes implied by seasonal changes in atmospheric oxygen: the role of heterotrophic microbes, Aquat. Microb. Ecol. 11 (1996) 91-100.

[59] Shiah F.-K., Ducklow H.W., Bacterioplankton growth responses to temperature and chlorophyll variations in estuaries measured by thymidine:leucine incorporation ratio, Aquat. Microb. Ecol. 13 (1997) 151-159.

[60] Simon M., Azam F., Protein content and protein synthesis rates of planktonic marine bacteria, Mar. Ecol. Prog. Ser. 51 (1989) 201-213.

[61] Simon M., Cho, B.C., Azam F., Significance of bacterial biomass in lakes and the ocean: comparison to phytoplankton biomass and biogeochemical implications, Mar. Ecol. Prog. Ser. $86(1992) 103-110$.

[62] Strickland J.D.H., Parsons T.R., A practical handbook of seawater analysis. Bull. Fish. Res. Board of Canada, 167, 2nd ed., (1972) $310 \mathrm{p}$.

[63] Suzuki M., Sherr E.B., Sherr B.F., DAPI direct counting under estimates bacterial abundances and average cell size compared to A.O. direct counting, Limnol. Oceanogr. 38 (7) (1993) $1556-1570$

[64] Torréton J.P., Importance de bactéries hétérotrophes aérobies dans une lagune eutrophe tropicale (Lagune Ebrié). Biomasse, productions, exportations, Thèse de Doctorat d'Université. Université d'Aix-Marseille II (1991) $246 \mathrm{p}$.

[65] Tremblay J.-E., Legendre L., A model for the size-fractionated biomass and productivity of marine productivity, Limnol. Oceanogr. 39 (1994) 2004-2014.

[66] Tremblay J.-E., Legendre L., Therriault J.-C., Size-differential effects of vertical stability on the biomass and production of phytoplankton in a large estuarine system, Est. Coast. Sh. Sc. 45 (1997) 415-431.

[67] Turley C.M., Hughes D.J., Effects of storage on direct estimates of bacterial numbers of preserved seawater samples. Deep Sea Res. 39, 3/4, (1992) 375-394.

[68] Vaqué D., Seasonal dynamics of planktonic microbial communities on the coast of the northwest Mediterranean Sea, Publ. Espec. Inst. Esp. Occanogr. 22 (1996) 39-46.

[69] Weber O., Jouanneau J.M., Ruch P., Mirmand M., Grain-size relationship between suspended matter originating in the Gironde estuary and shelf mud-patch deposits, Mar. Geol. 96 (1991) 159-165.

[70] Yentsch C.S., Menzel D.W., A method for the determination of phytoplankton chlorophyll and phaeophytin by fluorescence, Deep Sea Res. 10 (1963) 221-231. 